\title{
FAKTOR-FAKTOR YANG MEMPENGARUHI PERILAKU PEMBERIAN ASI EKSKLUSIF PADA IBU YANG MEMILIKI BAYI USIA 0-24 BULAN DIPOSYANDU MENUR 049 SAMARINDA
}

\author{
Endang Wiwiek.P ${ }^{1}$, Sri Utami ${ }^{2}$.,Valirianus $\mathrm{D}^{3}$.,Donata Tea ${ }^{4}$ \\ Prodi DIII Keperawatan STIKES Dirgahayu Samarinda ${ }^{1,2,3,4}$ \\ J1. Pasundan No. 21 Kelurahan Jawa Kota Samarinda \\ wpurnamawaty@yahoo.co.id
}

\begin{abstract}
ABSTRAK
ASI eksklusif adalah bayi yang hanya diberi ASI saja, tanpa bahan tambahan cairan lain seperti susu formula, jeruk, madu, air teh, air putih, dan tanpa bahan tambahan makanan padat seperti pisang, pepaya, bubur susu, biskuit, bubur nasi dan tim (Roesli,2010). Tujuan penelitian ini untuk mengetahui faktor-faktor yang mempengaruhi perilaku pemberian ASI eksklusif di posyandu Menur 049 Samarinda. Analisis bivariat menggunakan chi square dan fisher's exact test. Analisis bivariat menunjukkan faktor usia ibu tidak mempengaruhi sikap ibu terhadap pemberian ASI eksklusif dengan hasil $p$ value $0.556>0.05$, tingkat pendidikan tidak mempengaruhi sikap ibu terhadap pemberian ASI eksklusif dengan hasil $p$ value $1.00>0.05$, pekerjaan tidak mempengaruhi sikap ibu terhadap pemberian ASI eksklusif dengan hasil $p$ value $1.00>0.05$, paritas tidak mempengaruhi sikap ibu terhadap pemberian ASI eksklusif dengan hasil $p$ value $0,605>0.05$. Teknik pengambilan sampel menggunakan total sampling berjumlah 39 responden.. Pengumpulan data menggunakan instrumen penelitian yaitu angket berupa kuesioner.
\end{abstract}

Kata kunci : ASI eksklusif, perilaku, pemberian

\section{PENDAHULUAN}

$$
\text { Bayi usia 0-6 bulan sangat }
$$

membutuhkan ASI Eksklusif untuk membentuk kekebalan tubuh dari berbagai macam penyakit, serta merupakan gizi yang sangat baik untuk pertumbuhan dan perkembangan bayi yang optimal. Bayi yang tidak mendapatkan ASI Eksklusif akan menyebabkan bayi rentan terhadap penyakit sehingga mudah terkena penyakit infeksi (Penirasia, 2006). Menurut Riset Kesehatan Dasar di Provinsi Kaltim tahun 2013-2018, pemberian ASI Ekslusif menurun dari 69\% pada tahun 2013 menjadi $32,2 \%$ pada tahun 2018 .

Berdasarkan latar belakang di atas , maka penulis tertarik melakukan penelitian mengenai faktor-faktor yang mempengaruhi perilaku pemberian ASI eksklusif pada ibu yang memiliki bayi usia 0-24 bulan diposyandu Menur 049 Samarinda.

\section{METODE PENELITIAN}

Penelitian ini adalah penelitian deskriptif dimana peneliti menguraikan tentang faktor-faktor yang mempengaruhi perilaku pemberian ASI eksklusif pada ibu yang memiliki bayi usia 0-24 bulan diposyandu Menur 049 Kelurahan Bugis Samarinda Kota. 


\section{Hasil Penelitian}

\section{Tabel 1. Karakteristik Usia Responden}

\begin{tabular}{|c|c|c|}
\hline Variabel & Frekuensi & $\%$ \\
\hline$<20$ & 1 & 2,6 \\
\hline $21-30$ & 19 & 48.7 \\
\hline $31-40$ & 15 & 38.5 \\
\hline $41-50$ & 4 & 10.3 \\
\hline Total & 39 & 100 \\
\hline
\end{tabular}

Pada penelitian ini dari 39 responden peserta usia 21-30 sebanyak 19 orang (48.7\%)

Tabel 2. Karakteristik Pendidikan Responden

\begin{tabular}{lcc}
\hline \multicolumn{1}{c}{ Variabel } & Frekuensi & Persen \\
\hline Rendah & 15 & 38.38 .5 \\
Tinggi & 24 & 61.5
\end{tabular}

\begin{tabular}{lllll}
\hline Total & 39 & 100 & \\
\hline Berdasarkan & hasil & penelitian & dari & 39
\end{tabular}
responden 24 orang mempunyai pendidikan tinggi. $(61.5 \%)$

Tabel 3. Karakteristik Pekerjaan Responden

\begin{tabular}{llll}
\hline \multicolumn{1}{c}{ Variabel } & Frekuensi & Persen & \\
\hline IRT & 23 & 74.4 & \\
Swasta & 7 & 17.9 & \\
PNS & 3 & 7.7 & \\
& & & \\
Total & 39 & 100 & \\
\hline Berdasarkan hasil penelitian dari & 39 \\
responden sebagai ibu rumah tangga & 23 \\
orang $(74.4 \%)$.
\end{tabular}

Tabel 4. Karakteristik Paritas Responden

\begin{tabular}{lll}
\hline \multicolumn{1}{c}{ Variabel } & Frekuensi & Persen \\
\hline I kali & 19 & 48.7 \\
2 kali & 12 & 30.8 \\
3 kali & 8 & 20.5 \\
& & \\
\hline Total & 39 & 100 \\
\hline
\end{tabular}

Berdasarkan hasil penelitian dari 39 responden untuk paritas 1 kali ada 19 orang $(48.7 \%)$.

\section{PEMBAHASAN}

1. Pemberian ASI eksklusif berdasarkan usia responden

Hasil uji SPSS versi 20 menunjukkan bahwa nilai $X^{2}$ hitung dari uji Fisher's Exact Test adalah 1,121 dan dk =(21) $(2-1)=1$, dengan $\alpha=0,05$ diperoleh $X^{2}$ tabel $=2,706$. Karena $X_{\text {hitung }}^{2}=1,121<X_{\text {tabel }}^{2}=$ 2,706 dan sig $(0,556)>\alpha(0,05)$, yang berarti bahwa tidak ada hubungan antara faktor umur ibu terhadap pemberian ASI eksklusif pada ibu yang memiliki bayi 0-24 bulan diposyandu Menur 049 Samarinda. Hal ini menunjukkan responden merasa wajib memberikan ASI eksklusif kepada anaknya.

\section{Tingkat Pendidikan Responden Terhadap Pemberian ASI Eksklusif}

Nilai $X_{\text {hitung }}^{2}$ dari uji Fisher's Exact Test adalah 0,036 dan $\mathrm{dk}=(2-1)(2-1)=1$, dengan $\alpha=0,05$ diperoleh $X^{2}$ tabel $=2,706$. Karena $X_{\text {hitung }}^{2}=0,036<X_{\text {tabel }}^{2}=2,706$ dan sig $(1,000)>\alpha(0,05)$, yang berarti bahwa tidak ada hubungan antara faktor pendidikan terhadap pemberian ASI eksklusif pada ibu yang memiliki bayi 0-24 bulan diposyandu Menur 049 Samarinda. Hal ini menunjukkan seorang responden merasa tetap mengutamakan memberikan ASI eksklusif terbaik kepada anaknya yang masih berumur 0-24 bulan diposyandu Menur 049 Samarinda.

\section{Pemberian ASI eksklusif berdasarkan paritas responden}

Sebanyak 39 responden nilai $X_{\text {hitung }}^{2}$ dari uji Fisher's Exact Test adalah 0,419 dan $\mathrm{dk}=(2-1)(2-1)=1$, dengan $\alpha=0,05$ diperoleh $X_{\text {tabel }}^{2}=2,706$. Karena $X_{\text {hitung }}^{2}=$ $0,419<X_{\text {tabel }}^{2}=2,706$ dan $\operatorname{sig}(, 605)>\alpha$ 
$(0,05)$, yang berarti bahwa tidak ada hubungan antara faktor paritas ibu terhadap pemberian ASI eksklusif yang memiliki bayi 0-24 bulan.

\section{Pemberian ASI eksklusif berdasarkan pekerjaan responden \\ Nilai $X_{\text {hitung }}^{2}$ dari uji Fisher's Exact}

Test adalah 0,101 dan $\mathrm{dk}=(2-1)(2-1)=1$, dengan $\alpha=0,05$ diperoleh $X_{\text {tabel }}^{2}=2,706$. Karena $X_{\text {hitung }}^{2}=0,101<X_{\text {tabel }}^{2}=2,706$ dan $\operatorname{sig}(1,000)>\alpha(0,05)$, yang berarti bahwa tidak ada hubungan antara faktor pekerjaan ibu terhadap pemberian ASI eksklusif.

\section{Kesimpulan}

Berdasarkan analisis data dan intepretasinya, maka dapat ditarik kesimpulan factor yang mempengaruhi pemberian ASI eksklusif adalah sebagai berikut:

1. Responden dalam penelitian berjumlah 39 orang, berusia $\leq 35$ tahun sebanyak 29 orang $(74,4 \%)$ dan usia $\geq 35$ tahun sebanyak 10 orang $(25,6 \%)$

2. Tingkat pendidikan ibu dalam penelitian ini adalah rendah (SD-SMP) yaitu sebanyak 15 orang (38.5\%), pendidikan tinggi (SMA-PT) sebanyak 24 orang $(61,5 \%)$

3. Berdasarkan pekerjaan sebagai ibu rumah tangga 23 orang $(74,4 \%)$, karyawan swasta 7 orang $(17,9 \%)$ dan sebagai PNS 3 orang $(7,7 \%)$.

4. Responden dengan paritas 1 kali 20 orang $(48,7 \%)$ dan untuk paritas $\geq 1$ kali19 orang $(51,3 \%)$

5. Hasil analisa menunjukkan bahwa usia ibu tidak mempengaruhi sikap ibu terhadap pemberian ASI eksklusif dengan hasil $p$ value $0.556>0.05$.

6. Hasil analisa menunjukkan bahwa tingkat pendidikan tidak mempengaruhi sikap ibu terhadap pemberian ASI eksklusif dengan hasil $p$ value $1.00>0.05$.
7. Hasil analisa menunjukkan bahwa pekerjaan tidak mempengaruhi sikap ibu terhadap pemberian ASI eksklusif dengan hasil $p$ value $1.00>0.05$.

8. Hasil analisa menunjukkan bahwa paritas tidak mempengaruhi sikap ibu terhadap pemberian ASI eksklusif dengan hasil $p$ value $0,605>0.05$.

\section{Saran}

Berdasarkan kesimpulan hasil penelitian , maka disarankan sebagai berikut :

1. Pada hasil penelitian ini ditemukan bahwa usia, tingkat pendidikan dan pekerjaan dan paritas tidak mempengaruhi sikap ibu terhadap pemberian ASI eksklusif, karena keterbatasan peneliti sehingga perlu dilakukan penelitian lebih lanjut dengan jumlah sampel yang lebih besar, metode sampling yang lebih akurat dengan mengendalikan factor perancu.

2. Melakukan pendidikan kesehatan kepada calon ibu mengenai pentingnya pemberian ASI eksklusif.

3. Kepada Tenaga Puskesmas / Kesehatan Diharapkan kepada seluruh tenaga kesehatan dapat memberikan penyuluhan tentang manfaat air susu ibu dan bagaimana cara menyusui bayi yang benar.

4. Bagi Peneliti Selanjutnya

a. Bagi peneliti selanjutnya diharapkan dapat melakukan penelitian lebih baik dari yang sudah ada dengan memperhatikan keterbatasan penelitian ini.

b. Kaji mengenai kondisi biologis,psikologis, keadaan social budaya klien dan mengikut sertakan anggota keluarga saat penyuluhan.

DAFTAR PUSTAKA

Arikunto, S. 2008. Prosedur Penelitian, Rineka Cipta: Jakarta 
Arif, N. 2009. ASI dan Tumbuh Kembang Bayi. Jakarta: MedPress

Arini , H. 2012. Mengapa Seorang Ibu Harus Menyusui?. Jakarta: Flash Book.

Astuti, I. 2013. Determinan Pemberian ASI Eksklusif pada Ibu Menyusui. Journal Health Quality, 4(1). Diunduh dari www.poltekkesjakarta1.ac.id

Azwar S. 2007. Konsep Dan Penerapan Metodologi Penelitian. Jakarta : Rineka Cipta.

-------------- 2012. Konsep Metodologi Penelitian. Yogyakarta : Pustaka Pelajar

Dahlan, A., Mubin, F., Mustika, D. 2013. Hubungan Status Pekerjaan dengan Pemberian Asi Eksklusif di Kelurahan Palebon Kecamatan Pedurungan Kota Semarang. Jurnal Unimus. Diunduh dari http://jurnal.unimus.ac.id

Departemen Kesehatan RI. 2007. Pelatihan Konseling Laktasi: Panduan Peserta.

Diunduh dari http://gizi.depkes.go.id

Departemen Pendidikan Naional. 2005. Kamus Besar Bahasa Indonesia. Jakarta:PT. Gramedia Pustaka

Ida, 2011. Faktor-faktor yang berhubungan dengan pemberian ASI eksklusif 6 bulan diwilayah kerja puskesmas Kemiri Muka Kota Depok Diunduh dari http://ejournal.litbang.depkes.go.id/inde x.php/kespro/article

Ikatan Dokter Anak Indonesia. 2010. Indonesia Menyusui. Jakarta: Badan Penerbit IDAI

Kristiyanisari, W. 2009. ASI, Menyusui \& Sadari. Yogyakarta: Nuha Medika

Notoatmodjo. 2010. Promosi kesehatan teori dan aplikasi edidi revisi. 2010.. Jakarta : Rieneka Cipta.

-------------. 2012. Metode Penelitian Kesehatan. Jakarta : Rieneka Cipta.
Nursalam, 2008. Konsep dan Penerapan Metodologi Penelitiaan Keperawatan. Jakarta : Salemba Medika.

Roesli, U, 2008, Inisiasi Menyusu Dini Plus ASI Eksklusif, Jakarta: Pustaka Bunda 2010. Mengenal ASI Eksklusif. Jakarta: Pustaka Bunda

Proverawati, A dan Rahmawati, E. 2010. Kapita Selekta ASI dan Menyusui. Yogyakarta: Nuha Medika

astroasmoro,2014.Dasar-Dasar Metodologi Penelitian Klinis.Jakarta:Sagung Seto

Siti Fatimah, 2017. Hubungan Karakteristik dan pengetahuan ibu dengan pemberian ASI Eksklusif diwilayah kerja puskesmas Turi.

Siti Nasrah, 2018. Faktor penyebab kegagalan ASI eksklusif pada bayi 0 6 bulan diwilayah kerja puskesmas Kolono kabupaten Konawe selatan

Syera Mahyuni,2017. Pengetahuan ibu tentang pemberian asi eksklusif di kelurahan Aek tampang, kecamatan Padang Sidempuan selatan, Jurnal Warta Edisi 56 April 2018 | ISSN : 1829 - 7463 